\title{
Spatial and Temporal Variability of Moisture Condition in Soil-Plant Environment using Spectral Data and Gis Tools
}

\author{
Henryk Grzywna ${ }^{1 *}$, Paweł B. Dąbek', Beata Olszewska' \\ 1 Wrocław University of Environmental and Life Sciences, Institute of Environmental Protection and \\ Development, pl. Grunwaldzki 24, 50-363 Wrocław, Poland \\ * Corresponding author's e-mail: henryk.grzywna@upwr.edu.pl
}

\begin{abstract}
The studies on agricultural droughts require long-term atmospheric, hydrological and meteorological data. On the other hand, today, the possibilities of using spectral data in environmental studies are indicated. The development of remote sensing techniques, increasing the spectral and spatial resolution of data allows using remote sensing data in the study of water content in the environment. The paper presents the results of the analysis of moisture content of soil-plant environment in the lowland areas of river valley using the spectral data from Sentinel-2. The analyses were conducted between February and November 2016. The spectral data were used to calculate the Normalize Differential Vegetation Index (NDVI) which provided the information about the moisture content of the soil-plant environment. The analyses were performed only on grasslands, on 22 objects located in the research area in the Oder river valley between Malczyce and Brzeg Dolny, Poland. The NDVI values were correlated with the hydrological and meteorological parameters. The analyses showed spatial and temporal variability of the moisture conditions in the soil-plant environment showed by the NDVI variability and existence some relationships between the climatic and spectral indices characterizing the moisture content in the environment.
\end{abstract}

Keywords: drought, soil moisture, NDVI, Sentinel-2, satellite data, remote sensing

\section{INTRODUCTION}

The human has no influence on the occurrence of drought and can only affect the social, economic, technical or political factors that present the scale of the phenomenon in a given region [Jarząbek et al. 2013, Łabędzki and Bąk 2013]. Drought is a climatic phenomenon defined as a noticeable lack of water. It causes damage to nature and the economy, as well as a nuisance to the population and even a threat to human life [Nichol and Abbas 2015, Hisdal and Tallaksen 2000]. Precipitation is the main source of water supply for plants and their amount and distribution are regarded as a factor determining their size and conditions [Dzieżyc et al. 1987]. The dynamics of changes in soil moisture significantly affect the condition of plants and crops, the moisture deficit reduces the quantity and quality of yields, which results in, i.a. the losses in the economy and agriculture [Dubicki et al. 2002]. In a surface layer of a soil, where the scale and dynamics of moisture changeability is the largest, the impact of precipitation variability is visible the most [Lauzon et al. 2004]. The soil properties that affect the water holding capacity are particularly important from the agricultural point of view [Biniak-Pieróg 2008, Jankowiak and Bieńkowski 2011]. Soil retention has a fundamental role in the water balance of the agricultural areas [Nyc 1994, Pływaczyk and Olszewska 2014].

Agricultural drought is a state in which the soil moisture is insufficient to meet the water needs of plants [Łabędzki and Bąk 2015a, Nyc 1994]. The studies pertaining to agricultural droughts are focused mainly on using the methods based on the long-term atmospheric data, temperature, precipitation and evaporation measurements without considering the changes in soil properties and parameters. Such analyses characterize local habitats and they are only representative for small areas [Martínez-Fernández et al. 2016, Torres et al. 
2013]. The data comes from a wide measurement network, only in limited number of cases [Jackson et al. 2004]. Remote sensing measurements and analyzes using GIS technology have only enabled obtaining the current information about soil moisture in large areas, mainly in upper (active) soil layer [Łabędzki and Bąk 2015].

Currently, remote sensing techniques are rapidly developing. New devices, enabling to use cameras installed on aircraft boards and unmanned aerial vehicles or using satellites have appeared. The quick and significant increase in a satellite remote sensing in the spectral and spatial resolution are observed - from NOAA (National Oceanic and Atmospheric Administration) satellite with spatial resolution ca. $1000 \mathrm{~m}$, through Landsat satellite series with spatial resolution 100 $\mathrm{m}$ to $20 \mathrm{~m}$, to one of the latest Sentinel-2 missions with spatial resolution 10 and $20 \mathrm{~m}$ [Drusch et al. 2012]. In an aircraft-based remote sensing using hyperspectral device, it is possible to obtain the images with the spectral resolution of 1 $\mathrm{nm}$. Depending on the height from which the image will be taken, the spatial resolution can reach even $1 \mathrm{~cm}$ [Mohd et al. 2018].

The use of remote sensing techniques in the analyses of droughts is based mainly on employing spectral indicators for determining the condition of the vegetation (vegetation health) [Nicolai-Shaw et al. 2017, Dąbrowska-Zielińska et al. 2011]. Connecting the reflection of light with the biophysical characteristics of plants enabled to use the spectral indicators for assessing biomass production, forecasting of yields, and susceptibility of plant organisms to the influence of stressors such as water retention in the soil. It is possible to use plants as indicators in the study of soil-plant environment moisture [Dąbrowska-Zielińska et al. 2011], and thus in the assessment or even prediction of drought. Normalized Difference Vegetation Index (NDVI) [Pettorelli et al. 2005, Huete et al. 2002] is one of the most recognized and described spectral indices. This index is calculated based on the difference between reflectance of sunlight in the near-infrared and red bands normalized by the sum of both of them [Wójtowicz et al. 2005]. Its basic function is determining the amount of chlorophyll in the plants cells. According to this parameter, it is possible to determine the condition of the plant and its susceptibility to external stressors [Carlson and Ripley 1997]. NDVI can be used as a substitute indicator for assessing the water content in the environment be- cause of the correlation between the vegetation condition and availability of water and the hydrological regime [Taylor et al. 2003, Pettorelli et al. 2005]. The high value of the indicator is exhibited by dense vegetation growth in the favorable conditions for the environment. The NDVI value more than 0.5 identifies the plants in good condition [Carlson and Ripley 1997].

The aim of the study is to prove the possibility of using NDVI in the analyses of the relation between remote sensing indicator and meteorological and hydrological parameters. On the basis of the spectral images from Sentinel-2 NDVI values, the relations were calculated. The values of the indicator provided the information about the current state of the plants, their condition and reaction to the soil-plant environmental conditions and its variability. The correlation values will help to answer the question, if it is possible to use NDVI for monitoring agricultural and soil drought in lowland areas in the river valleys.

\section{MATERIALS AND METHODS}

The study area is located on the left bank of the Oder River valley from city of Brzeg Dolny to Malczyce, in Lower Silesian voivodeship, in Poland (N: 51 ${ }^{\circ} 13^{\prime}$ 53.51", E: $16^{\circ} 40^{\prime} 47.02$ ". PL-92: 338057, 338057) (Figure 1) [Olszewska et al. 2012]. Since 1993, the studies of soil moisture measurements and the analyses of ground water tables and water levels in the rivers have been conducted in the area. The area of analyses is mainly under the agricultural use, there are only scattered buildings. The research area is $7.73 \mathrm{~km}^{2}$. This paper presents the analyses which were carried out from February to November 2016.

The spectral data for the analyses were obtained from the Sentinel-2 satellite of European Space Agency (ESA). The set comprises the two satellites: Sentinel-2A and Sentinel-2B which move simultaneously. The main instrument of Sentinel-2 satellite is a single multi-spectral instrument (MSI) with 13 spectral channels, in the spectral range of 413-2210 nm with a spatial range from 10 to $60 \mathrm{~m}$ [Drusch et al. 2012]. ESA for scientific purposes provides data of varying degrees of processing, available on the Sentinels Scientific Data Hub website. For the presented study, the data referred to as $2 \mathrm{~A}$ were obtained. These include the data pertaining to the reflection in the top of atmosphere and they are after 


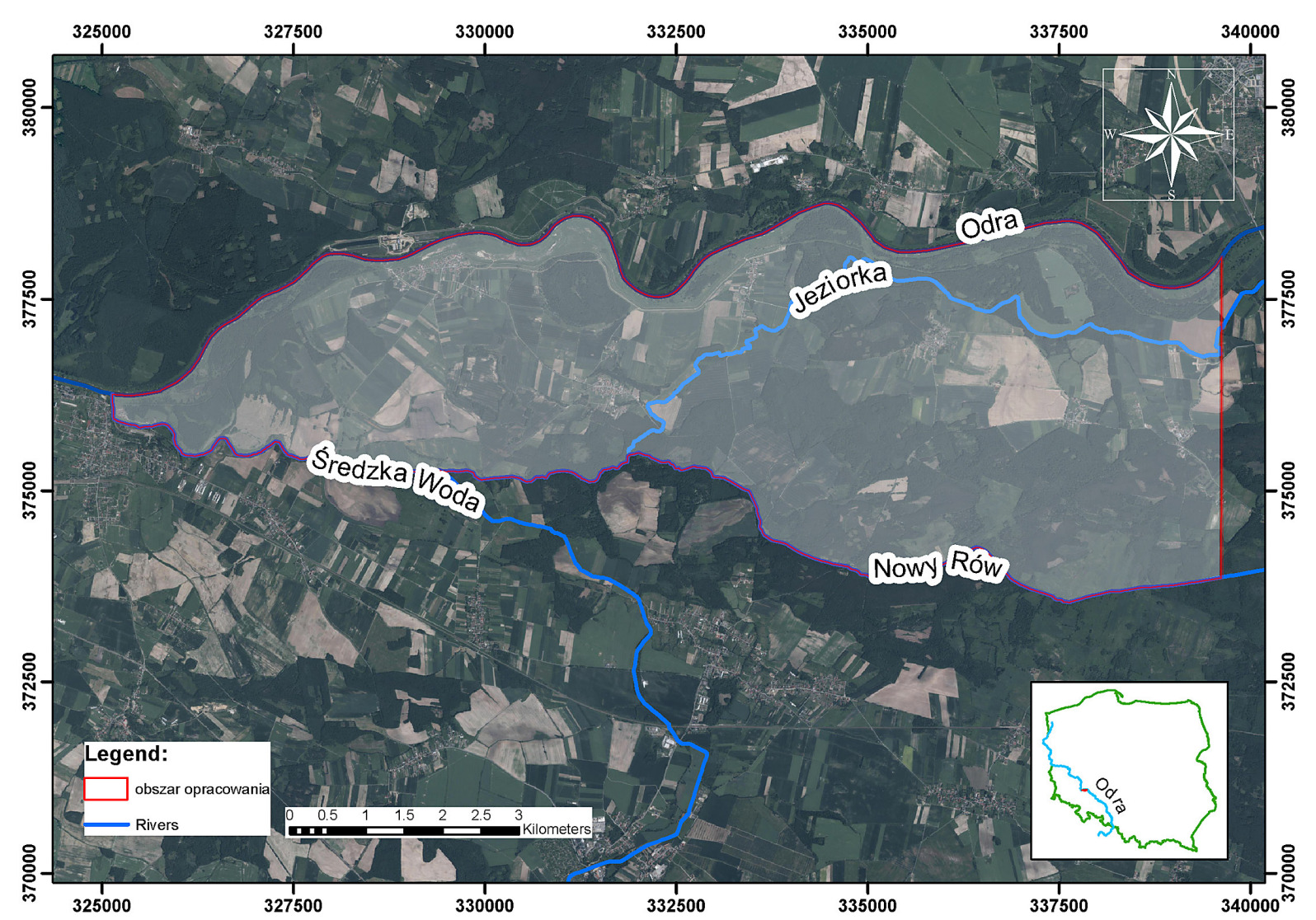

Figure 1. Location of the study area in the left bank of the Odra River valley.

necessarily radiometric and geometric corrections. In order to obtain the surface reflection, MSI bands were scaled to surface reflectance using Dark Object Subtraction (DOS) methods in Semi-Automatic Classification Plugin for QGIS [Congedo 2016]. The spectral images prepared in this way were used to determine the relevant spectral indicators.

Eight spectra images with a cloud cover less than $5 \%$ for the research area were selected from Sentinel-2 mission: Feb 6, March 17, March 27, May 6, Jun 25, Aug 4, Sep 13 and Nov 22.

Daily sum of precipitation $[\mathrm{mm}]$, average daily temperature $\left[{ }^{\circ} \mathrm{C}\right]$ for Wrocław-Strachowice station, water levels $[\mathrm{cm}]$ in the Odra from the gauge stations of Brzeg Dolny were obtained from the Institute of Meteorology and Water Management - National Research Institute. This iconforms to the act of the re-use of public sector information, which implements the directive 2013/37/UE into Polish law. The Climatic Water Balance was calculated by means of the Jaworski method [Jaworski 2004], with regard to the evapotranspiration rate according to the model of Doroszewski and Górski [Doroszewski and Górski 1995]. For the basic analysis, the average tem- perature (T.mean), the precipitation sum (P.sum), the average water level (W.mean) and the climatic water balance (CWB) for periods of 5, 10, 20 and 30 days before the satellite image was taken, were calculated (Table 1). The adopted meteorological and hydrological parameters were the same for the entire research area. This was related to the fact that the individual research objects are close to each other and to the reference station.

The basic analyses were conducted in two consecutive phases. The first phase included selection of grasslands from other types of the land cover on the research area and calculation the NDVI for grasslands for every object (Figure 2). In the second phase, the statistical analyses of correlation between data describing moisture condition in soil-plan environment on the research area were conducted. Correlation was done between the in situ (meteorological and hydrological) data and spectra data describing state and condition of plants (indicator of environmental moisture) [Dąbrowska-Zielińska et al. 2011].

The analyses were performed on grassland. The condition of the grassland depends only on the availability of water resources, not on the growth stages during the vegetation season. It 
Table 1. Specification of meteorological and hydrological data (T.mean - average temperature $\left[{ }^{\circ} \mathrm{C}\right]$; P.sum precipitation sum [mm]; W.mean - average water level [cm]; CWB - climatic water balance [mm]; 5, 10, 20, 30 - the length of the previous period [days]).

\begin{tabular}{|c|c|c|c|c|c|c|c|c|c|c|c|c|c|c|}
\hline Date & $\begin{array}{c}\text { T.mean } \\
5\left[{ }^{\circ} \mathrm{C}\right]\end{array}$ & $\begin{array}{l}\text { T.mean } \\
10\left[{ }^{\circ} \mathrm{C}\right]\end{array}$ & $\begin{array}{l}\text { T.mean } \\
20\left[{ }^{\circ} \mathrm{C}\right]\end{array}$ & $\begin{array}{l}\text { T.mean } \\
30\left[{ }^{\circ} \mathrm{C}\right]\end{array}$ & $\begin{array}{c}\text { P.sum } \\
5 \\
{[\mathrm{~mm}]}\end{array}$ & $\begin{array}{c}\text { P.sum } \\
10 \\
{[\mathrm{~mm}]}\end{array}$ & $\begin{array}{c}\text { P.sum } \\
20 \\
{[\mathrm{~mm}]}\end{array}$ & $\begin{array}{c}\text { P.sum } \\
30 \\
{[\mathrm{~mm}]}\end{array}$ & $\begin{array}{l}\text { W.mean } \\
10[\mathrm{~cm}]\end{array}$ & $\begin{array}{l}\text { W.mean } \\
20[\mathrm{~cm}]\end{array}$ & $\begin{array}{c}\text { CWB } \\
5 \\
{[\mathrm{~mm}]}\end{array}$ & $\begin{array}{c}\text { CWB } \\
10 \\
{[\mathrm{~mm}]}\end{array}$ & $\begin{array}{c}\text { CWB } \\
20 \\
{[\mathrm{~mm}]}\end{array}$ & $\begin{array}{c}\text { CWB } \\
30 \\
{[\mathrm{~mm}]}\end{array}$ \\
\hline Feb 6, 2016 & 6.4 & 6.9 & 2.8 & 2.2 & 5.8 & 12.9 & 26.7 & 41.4 & 115.0 & 89.0 & 7.0 & 14.7 & 30.8 & 46.8 \\
\hline March 17, 2016 & 3.6 & 3.7 & 3.3 & 3.6 & 6.6 & 21.5 & 49.0 & 71.8 & 251.0 & 246.0 & -14.0 & 2.6 & 30.4 & 53,6 \\
\hline March 27, 2016 & 6.3 & 5.8 & 4.8 & 4.2 & 4.5 & 5.1 & 26.6 & 54.1 & 214.0 & 232.0 & -23.7 & -23.3 & 0.4 & 27.1 \\
\hline May 6, 2016 & 12.3 & 10.1 & 9.4 & 9.8 & 21.2 & 23.5 & 33.3 & 67.6 & 176.0 & 204.0 & -37.7 & -36.5 & -36.9 & -5.6 \\
\hline June 25, 2016 & 22.2 & 20.4 & 19.4 & 19.4 & 4.4 & 37.4 & 41.4 & 46.7 & 80.0 & 89.0 & -91.5 & -60.0 & -74.1 & -88.7 \\
\hline Aug 4, 2016 & 21.1 & 21.7 & 20.6 & 20.4 & 7.4 & 15.7 & 30.2 & 108.1 & 108.0 & 119.0 & -72.4 & -71.8 & -68.6 & -10.4 \\
\hline Sep 13, 2016 & 22.1 & 20.5 & 20.3 & 19.7 & 0.0 & 15.7 & 15.7 & 35.2 & 63.0 & 71.0 & -63.3 & -50.8 & -77.2 & -81.4 \\
\hline Nov 22, 2016 & 8.4 & 5.0 & 4.6 & 6.0 & 0.0 & 9.2 & 31.0 & 35.3 & - & - & 15.2 & 24.4 & 35.0 & 40.7 \\
\hline
\end{tabular}

is the opposite situation than in the case of cereals, for which the spectrum of the reflected light changes along with changes of phonological phase [Martyniak et al. 2007]. The analyses performed by the Institute of Environmental Protection and Development of Wrocław University of Environmental and Life Sciences showed that the water management of plants in a river valley between Brzeg Dolny and Malczyce based mainly on the use of water from precipitation and this is related to the fact of lowering the groundwater table [Pływaczyk and Olszewska 2014, Głuchowska and Pływaczyk 2008]. The ground water table is so deep that it reaches the levels which are not available for the root systems of most plants [Pływaczyk and Olszewska 2014, Chalfen et al. 2014].

Corine Land Cover 2012 was used for identification of grassland from other type of land cover. The result of the identification of the grassland areas was verified using the available material coming from the documentation from an older research conducted in the area. 22 objects were chosen for next analyses, which constituted compact complexes with the area greater than $150 \mathrm{~m}^{2}$. A grid with mesh size $10 \mathrm{~m}$ was used for analyses, which is consistent with the spatial resolution of Sentinel-2 data (Figure 2).

For each of the 22 objects, based on the NDVI value for every grid cell for 8 available scenes the median, minimum and maximum NDVI values were calculated used the formula [Kycko and Zagajewski 2013]:

$$
N D V I=\frac{(N I R-V I S)}{(N I R+V I S)}
$$

where: NIR- near infrared, Sentinel-2 band no. 8 , VIS - visible spectrum, Sentinel-2 band no. 4 [Drusch et al. 2012].
The statistical analyses were performed in the Statistica 13.1 software. In order to find out if the dependent variables (NDVI) and independent variables (meteorological and hydrological parameters) have a normal distribution the Shapiro-Wilk test were performed. The correlation between dependent and independent variables, describing the moisture conditions of the soil-plant environment, were sought next. The Pearson linear correlation coefficient was used to show the linear relationship of independent and dependent variable having a normal distribution. For the variable pairs where at least one did not have a normal distribution, the non-parametric Spearman correlation coefficient was used. The confidence interval of $95 \%$ was used.

\section{RESULTS}

For the objects having continuity of data in the analyzed period, the changes of the NDVI values for 8 measurement campaigns during the research period are presented in the chart (Figure 3). The objects are numbered from 1 to 23 ; due to technical reasons the object no. 2 was removed at the stage of data preparation (Figure 2).

The increase of NDVI values was observed in the following periods:

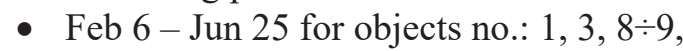

- Feb 6 - May 6 for objects no.: $5 \div 7,10,14 \div 15$, $18 \div 23$,

- Feb 6 - Aug 4 for objects no.: $11 \div 13,16 \div 17$,

- Feb 6 - Sep 13 for objects no.: 4 .

For the objects no. $1,4 \div 11,16 \div 23$ NDVI values exceeds 0.5 during the period of 6 th Feb to 13 th Sep which was $77 \%$ of objects. On this basis, it can be concluded that in this period the vegetation in the research area was in good condition at 


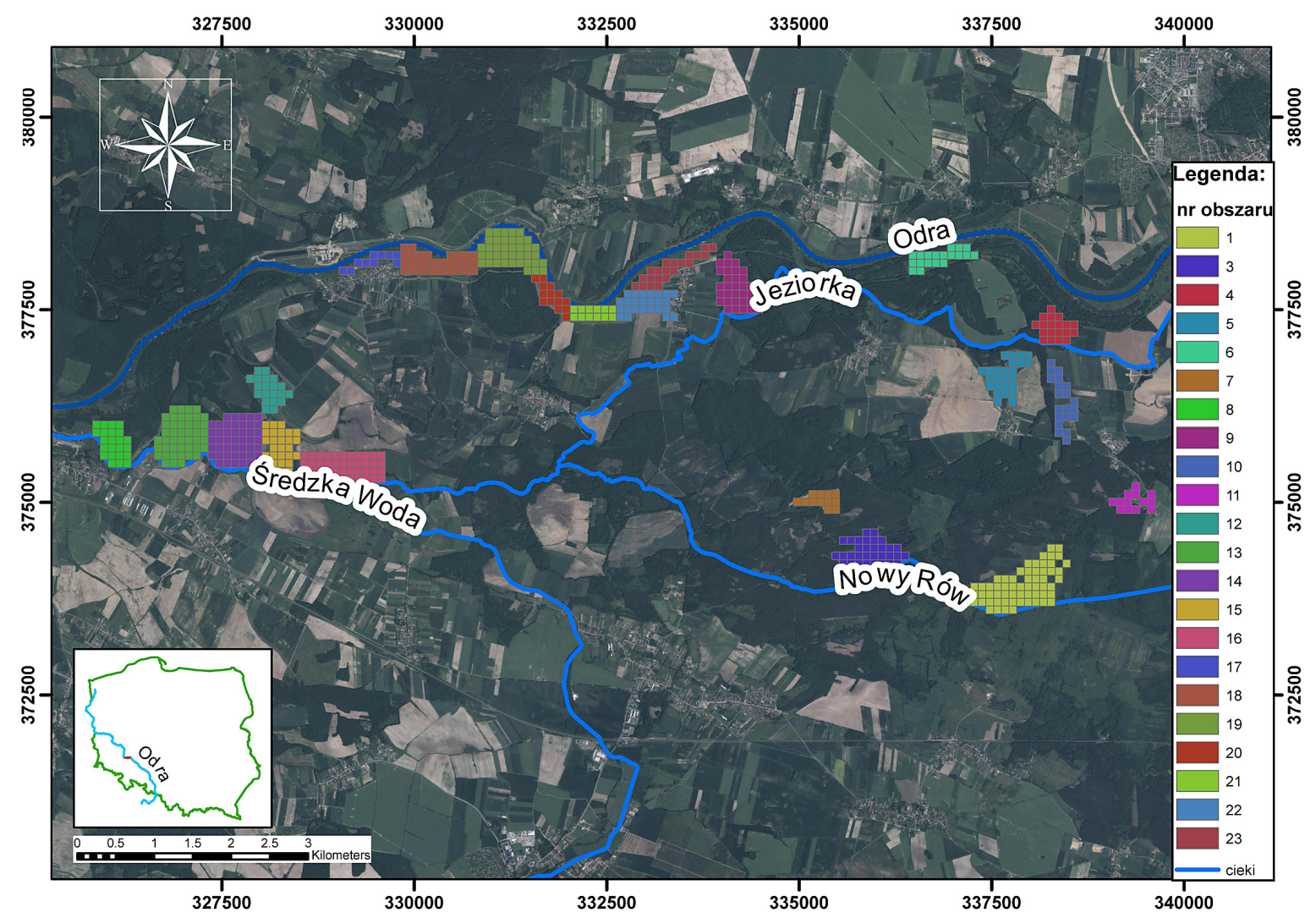

Figure 2. Location of the 22 objects in the research area, grid $10 \mathrm{~m}$.

the culminating point of vegetation in the end of this periods [Grzywna et al. 2018]. The median of NDVI had never increased above 0.5 for the object no. 15. For the object no. 14, the NDVI value was slightly higher than $0.5(0.52)$ on the 6th May. For object no. 12, the value of NDVI was higher than 0.5 for only one campaign on 4th Aug. The NDVI value was greater than 0.5 for objects no.: $4,6,8,11,16$, in the period from 6th Feb to 27th March. Most often, the NDVI value was higher than 0.5 for the objects $4,6 \div 7,9,11$ (6 times) and $7 \div 8,22 \div 23$ ( 5 times). However, for the objects 22 and 23, this occurred in the period from 6th May to 22nd Nov, whereas on other objects, in the period 17th Mar to 22nd Nov (Figure 3).

The smallest NDVI values were most often observed on the object no. 15 (3 times) and no. 12 (3 times) among the 8 campaigns on 22 objects. In each event, when the minimum value of NDVI was noted for object no. 12, the next lowest value was observed on the object no. 15.

The NDVI value was greater than 0.5 on each objects in the following dates: 6th Feb on none of the objects, 17th March on the objects no.: 4, 9, 11 ( 3 objects, $13.6 \%$ ). 27 th March on the objects no.: $4,6,8,16$ (4 objects, $18.2 \%$ ), 6th May on the objects no.: $1,4 \div 11,14,16 \div 23$ (18 objects, $81.8 \%$ ),
25 th Jun on the objects no.: $1,3,6 \div 9,11,17 \div 23$ (14 objects, $63.6 \%)$. 4th Aug on objects no.: 1, $3 \div 13,16 \div 20,22,23$ (19 objects $86.4 \%$ ), 13th Sep on the objects no.: $1,3 \div 11,13,17 \div 23$ (18 objects, $81.8 \%)$, 22nd Nov on the objects no.: 4, $6 \div 7,9$, $11,13,21 \div 23$ (9 objects, $40.1 \%$ ) (Table 2).

Normal distribution had the following independent variables: T.mean 5, P.sum 10, P.sum 20, P.sum 30, W.mean 10, W.mean 20, CWB 5, CWB 10, CWB 30 and distribution of the NDVI values (dependent variables) in the analyzed period for objects: $1,5,7 \div 8,10 \div 11,13 \div 14,16 \div 23$. Other variables did not have normal distribution.

In general, no correlation was found between the distribution of the NDVI values and independent variables in terms of the sum of precipitation and average water levels. Only between the NDVI values and P.sum 10 for about half of the objects was correlation found at the medium level $(0.50<\mathrm{R}<0.70)$.

For the analyzed objects in the research periods, no correlation was found between the NDVI values and precipitation and river water level. However, there is a noticeable difference in the case of the correlation between the NDVI values and average temperature or CWB. The thermal parameter had a positive correlation with NDVI. 


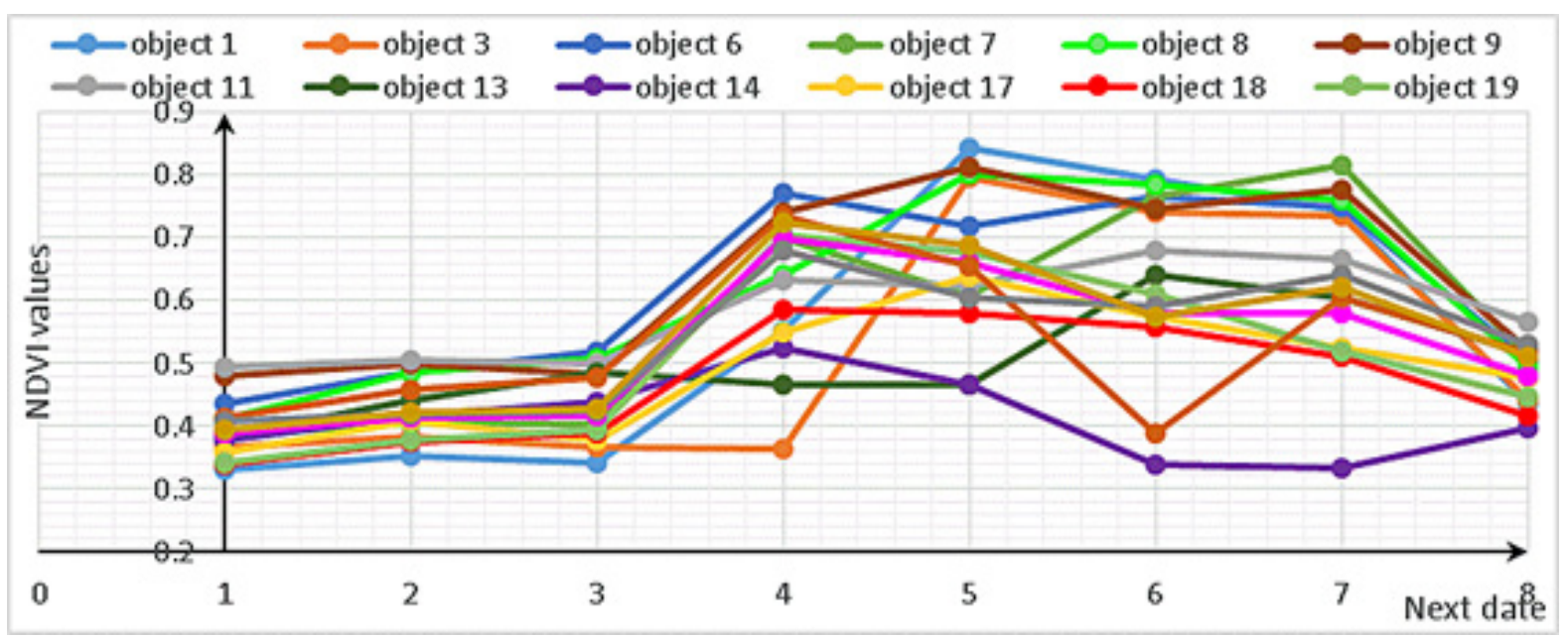

Figure 3. The NDVI values for subsequent measurement campaigns: 1 - Feb 6, 2 - Mar 17, 3 - Mar 27, 4 - May

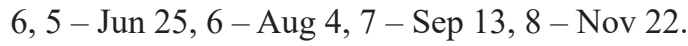

Table 2. Median value of NDVI indicator for 22 research objects in the following 8 campaigns

\begin{tabular}{|c|c|c|c|c|c|c|c|c|c|c|c|c|c|c|c|c|c|c|c|c|c|c|}
\hline $\begin{array}{c}\text { Campaign } \\
\text { [date] }\end{array}$ & 1 & 3 & 4 & 5 & 6 & 7 & 8 & 9 & 10 & 11 & 12 & 13 & 14 & 15 & 16 & 17 & 18 & 19 & 20 & 21 & 22 & 23 \\
\hline Feb 6 & 0.33 & 0.37 & 0.47 & 0.36 & 0.44 & 0.39 & 0.41 & 0.48 & 0.4 & 0.49 & 0.28 & 0.38 & 0.38 & 0.28 & 0.48 & 0.36 & 0.34 & 0.34 & 0.39 & 0.41 & 0.41 & 0.39 \\
\hline March 17 & 0.35 & 0.38 & 0.53 & 0.42 & 0.49 & 0.41 & 0.49 & 0.5 & 0.44 & 0.5 & 0.29 & 0.44 & 0.42 & 0.29 & 0.48 & 0.41 & 0.38 & 0.38 & 0.41 & 0.46 & 0.42 & 0.42 \\
\hline March 27 & 0.34 & 0.37 & 0.53 & 0.43 & 0.52 & 0.4 & 0.51 & 0.48 & 0.44 & 0.5 & 0.25 & 0.49 & 0.44 & 0.28 & 0.51 & 0.38 & 0.39 & 0.39 & 0.42 & 0.48 & 0.42 & 0.43 \\
\hline May 6 & 0.55 & 0.36 & 0.78 & 0.68 & 0.77 & 0.7 & 0.64 & 0.74 & 0.67 & 0.63 & 0.36 & 0.47 & 0.52 & 0.4 & 0.58 & 0.55 & 0.59 & 0.71 & 0.7 & 0.74 & 0.68 & 0.73 \\
\hline Jun 25 & 0.84 & 0.8 & $\mathrm{x}$ & $\mathrm{x}$ & 0.72 & 0.61 & 0.8 & 0.81 & $\mathrm{x}$ & 0.62 & $\mathrm{x}$ & 0.47 & 0.47 & $\mathrm{x}$ & $\mathrm{x}$ & 0.64 & 0.58 & 0.68 & 0.66 & 0.65 & 0.61 & 0.69 \\
\hline Aug 4 & 0.79 & 0.74 & 0.8 & 0.62 & 0.77 & 0.77 & 0.79 & 0.75 & 0.65 & 0.68 & 0.69 & 0.64 & 0.34 & 0.34 & 0.6 & 0.57 & 0.56 & 0.61 & 0.58 & 0.39 & 0.59 & 0.58 \\
\hline Sep 13 & 0.74 & 0.74 & 0.82 & 0.57 & 0.75 & 0.82 & 0.76 & 0.78 & 0.58 & 0.67 & 0.41 & 0.61 & 0.33 & 0.29 & 0.32 & 0.52 & 0.51 & 0.52 & 0.58 & 0.61 & 0.64 & 0.62 \\
\hline Nov 22 & 0.44 & 0.44 & 0.54 & 0.42 & 0.51 & 0.51 & 0.49 & 0.52 & 0.48 & 0.57 & 0.43 & 0.52 & 0.4 & 0.34 & 0.34 & 0.48 & 0.42 & 0.45 & 0.48 & 0.52 & 0.53 & 0.51 \\
\hline
\end{tabular}

This correlation stated that as the average temperature rises, the condition of plants represented by the increase in the NDVI values, increased proportionally. In the case of correlation to CWB, this was a reverse-proportional relationship - a negative correlation. As the value of CWB increased, the NDVI values decreased - the condition of plants decreased.

The correlations between the NDVI values and CWB 5, and CWB 30 were very high for many objects. The high and very high correlation $(\mathrm{R}>0.70)$ for more than half of the objects were recorded for the average temperature T.mean 5, T.mean 20 and T.mean 30, most objects showed the correlation for the T.mean 30 (over 75\%). Less than half of the objects showed a high and very high correlation between the NDVI values and T.mean 10 (Table 3).

The high and very high correlation for more than half of the objects was recorded for CWB 5, CWB 10, CWB 30. Less than half of the objects showed a high and very high correlation for CWB 20 (Table 3).
High or very high correlation between the NDVI values and all or almost all temperature and CWB indicators was exhibited by objects no.: $1,4 \div 9,11$. Objects no.: $3,12 \div 16$ and 21 did not show high or very high correlations or no other. Objects no.: $10,17 \div 20,22 \div 23$ showed a high or very high correlation to a part of the temperature value and CWB (Table 3).

\section{DISCUSSION AND CONCLUSION}

The analyses conducted by other researchers show high relevance of using the spectral data for assessing the plants condition and biomass production [Gao 1996, Martínez-Fernández et al. 2016]. NDVI shows the condition of plants based on the chlorophyll amount in the cells [Pettorelli et al. 2005]. Groeneveld and Baugh [2007] proved that NDVI can be used as an indicator of moisture content of the environment in which plants live and thus can be helpful in assessing the drought [Dąbrowska-Zielińska et al. 2011]. Bar- 

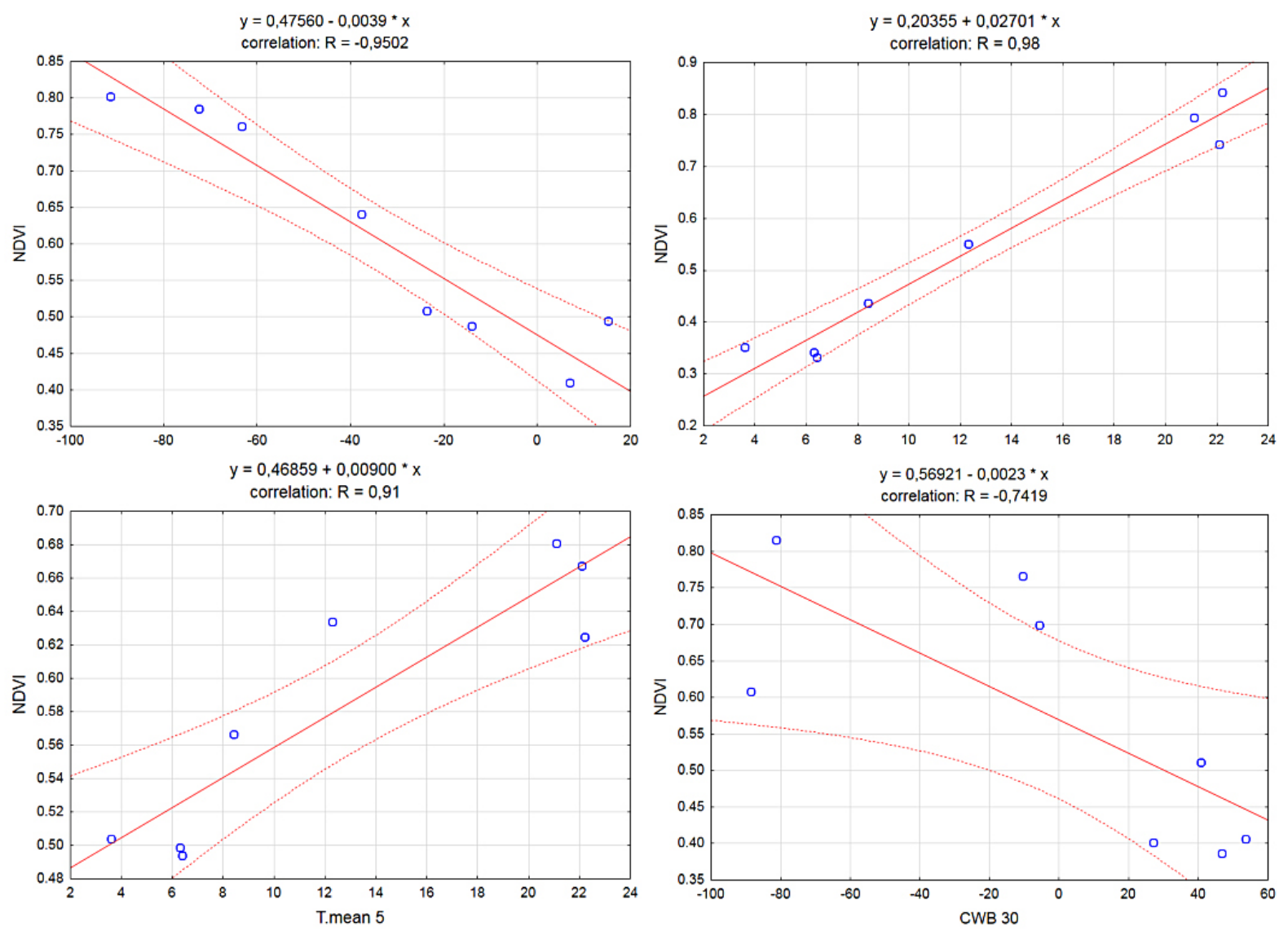

Figure 4. Selected of high or very high correlations $(R>0.70)$ between the NDVI values with selected independent variables along with regression equations (diagram $\mathrm{A}$ - object no. 1, diagram $\mathrm{B}$ - object no. 11, diagram $\mathrm{C}$ - object no. 8, diagram $\mathrm{D}$ - object no. 7).

bosa showed the high correlation $(0.84)$ between NDVI and precipitation which, in his opinion, is caused by the limited availability of precipitation [Barbosa et al. 2009]. Researchers conducted by authors like Plessis [1999] Schmidt and Gitelson [2000] showed close correlation between NDVI and precipitation, especially in dry and sub-humid environments, where precipitation is a factor limiting plant growth and their condition. However, the relationship between NDVI and precipitation is dependent on the characteristics of the type of vegetation and soil [Al-Bakri and Suleiman 2004]. It has been proven that NDVI can give a misrepresentation of the state of vegetation if the impact of greening - natural changes in the color of plants during the growing season, will not be removed [Wang et al. 2012]. Many factors, such as plant diseases, the amount of minerals or other stressors, can affect the NDVI values.

The changes in the index value (NDVI) do not necessarily have to be related to soil moisture [Nichol 2015]. This have been also confirmed by the studies conducted throughout the whole research area Brzeg Dolny - Malczyce in 2016
[Grzywna et al. 2018]. Similarly as for the whole research area, on particular objects, no high correlation was found between the NDVI values and precipitation or water levels.

It cannot be clearly determined which environmental parameter describing the moisture content in the environment has the highest impact on the NDVI value, representing the state of the plants.

The lack of correlation between the NDVI value and independent variables of precipitation and average water levels enables to state that it is impossible to use the NDVI in analysis of moisture content in soil-plane environment to forecast drought in agriculture.

High or very high correlation between NDVI, and temperature and CWB is a natural thing. This is related to the changes in the thermal conditions during the growing season.

There was no relationship between the location of the object on the research area and the values of the correlation between the NDVI and meteorological or hydrological parameters. 
Table 3. Values of correlation coefficients between the NDVI values and meteorological as well as hydrological parameters. $\mathrm{x}$ - no correlation $(\mathrm{R}<0.50) ; 0.50<\mathrm{R}<0.70$ - average correlation, $\mathrm{R}>0.70$ - high and very high correlation.

\begin{tabular}{|c|c|c|c|c|c|c|c|c|c|c|c|c|c|c|c|c|c|c|c|c|c|c|c|c|}
\hline \multirow{2}{*}{ Variable } & \multicolumn{24}{|c|}{ Object number } \\
\hline & 1 & 3 & 4 & & 5 & 6 & 7 & 8 & 9 & & 10 & 11 & 12 & 13 & 14 & 15 & 16 & 17 & 18 & 19 & 20 & 21 & 22 & 23 \\
\hline T.mean 5 & 0.98 & 0.64 & $0.8 \mathrm{~s}$ & & .74 & 0.64 & 0.87 & 0.96 & 0.9 & & .78 & 0.91 & 0.71 & 0.68 & $\mathrm{x}$ & 0.64 & $x$ & 0.86 & 0.83 & 0.74 & 0.76 & $x$ & 0.78 & 0.75 \\
\hline T.mean 10 & 0.71 & $x$ & 0.7 & & .68 & 0.71 & 0.74 & 0.79 & 0.69 & & 64 & 0.76 & $x$ & 0.55 & $x$ & $x$ & $\mathrm{x}$ & 0.67 & 0.62 & 0.62 & 0.6 & $\mathrm{x}$ & 0.62 & 0.6 \\
\hline T.mean 20 & 0.86 & 0.62 & 0.93 & & .89 & 0.86 & 0.88 & 0.93 & 0.83 & & .86 & 0.9 & 0.61 & 0.79 & $x$ & 0.57 & $x$ & 0.81 & 0.76 & 0.76 & 0.74 & $x$ & 0.76 & 0.74 \\
\hline T.mean 30 & 0.9 & 0.67 & 0.96 & & .86 & 0.83 & 0.93 & 0.9 & 0.88 & & .89 & 0.95 & 0.79 & 0.81 & $\mathrm{x}$ & 0.71 & $x$ & 0.86 & 0.79 & 0.79 & 0.76 & $\mathrm{x}$ & 0.79 & 0.76 \\
\hline P.sum 5 & $\mathrm{x}$ & $\mathrm{x}$ & $\mathrm{x}$ & & $\mathrm{x}$ & $\mathrm{x}$ & $\mathrm{x}$ & $\mathrm{x}$ & $\mathrm{x}$ & & $x$ & $\mathrm{x}$ & $\mathrm{x}$ & $\mathrm{x}$ & $x$ & $\mathrm{x}$ & 0.81 & $\mathrm{x}$ & $x$ & $\mathrm{x}$ & $\mathrm{x}$ & $\mathrm{x}$ & $x$ & $\mathrm{x}$ \\
\hline P.sum 10 & 0.58 & $\mathrm{x}$ & $\mathrm{x}$ & & .55 & $\mathrm{x}$ & $\mathrm{x}$ & 0.56 & 0.63 & & .51 & $\mathrm{x}$ & $\mathrm{x}$ & $\mathrm{x}$ & $x$ & 0.61 & $\mathrm{x}$ & 0.69 & 0.62 & 0.66 & 0.65 & 0.57 & $\mathrm{x}$ & 0.64 \\
\hline P.sum 20 & $\mathrm{x}$ & $\mathrm{x}$ & $\mathrm{x}$ & & $\mathrm{x}$ & $\mathrm{x}$ & $\mathrm{x}$ & $\mathrm{x}$ & $\mathrm{x}$ & & $x$ & $\mathrm{x}$ & $\mathrm{x}$ & $\mathrm{x}$ & $x$ & $x$ & $\mathrm{x}$ & $\mathrm{x}$ & $x$ & $x$ & $x$ & $x$ & $x$ & $x$ \\
\hline P.sum 30 & $\mathrm{x}$ & $\mathrm{x}$ & $\mathrm{x}$ & & $\mathrm{x}$ & $\mathrm{x}$ & $x$ & $\mathrm{x}$ & $\mathrm{x}$ & & 0.5 & $\mathrm{x}$ & $\mathrm{x}$ & $\mathrm{x}$ & $\mathrm{x}$ & $\mathrm{x}$ & 0.8 & $\mathrm{x}$ & $\mathrm{x}$ & $\mathrm{x}$ & $\mathrm{x}$ & $x$ & $x$ & $\mathrm{x}$ \\
\hline $\begin{array}{c}\text { W.mean } \\
10\end{array}$ & -0.75 & -0.57 & -0.6 & & $x$ & $x$ & -0.63 & -0.65 & -0.7 & & $\mathrm{x}$ & -0.65 & -0.66 & $\mathrm{x}$ & $x$ & $\mathrm{x}$ & $x$ & -0.57 & $x$ & $x$ & $\mathrm{x}$ & $\mathrm{x}$ & -0.54 & $x$ \\
\hline $\begin{array}{c}\text { W.mean } \\
20\end{array}$ & -0.62 & $\mathrm{x}$ & $\mathrm{x}$ & & $\mathrm{x}$ & $\mathrm{x}$ & $\mathrm{x}$ & $\mathrm{x}$ & $\mathrm{x}$ & & $x$ & $\mathrm{x}$ & $x$ & $\mathrm{x}$ & 0.51 & $\mathrm{x}$ & $\mathrm{x}$ & $\mathrm{x}$ & $\mathrm{x}$ & $\mathrm{x}$ & $\mathrm{x}$ & $\mathrm{x}$ & $\mathrm{x}$ & $\mathrm{x}$ \\
\hline CWB 5 & -0.91 & -0.6 & -0.7 & & 0.8 & -0.71 & -0.71 & -0.95 & -0.8 & & .78 & -0.75 & $x$ & -0.52 & $x$ & $\mathrm{x}$ & $x$ & -0.81 & -0.82 & -0.75 & -0.73 & $x$ & -0.65 & -0.7 \\
\hline CWB 10 & -0.86 & -0.57 & -0.7 & & 0.82 & -0.76 & -0.77 & -0.93 & -0.7 & & 0.8 & -0.79 & $\mathrm{x}$ & -0.62 & $x$ & $\mathrm{x}$ & $\mathrm{x}$ & -0.76 & -0.83 & -0.75 & -0.72 & $x$ & -0.67 & -0.68 \\
\hline CWB 20 & -0.76 & -0.52 & -0.7 & & 0.75 & -0.71 & -0.76 & -0.86 & $\mid-0.8$ & & .64 & -0.71 & $x$ & $x$ & $x$ & $x$ & $x$ & -0.69 & -0.64 & -0.64 & -0.69 & $x$ & -0.71 & $\mid$\begin{tabular}{|l}
$\mid$ \\
\end{tabular} \\
\hline CWB 30 & -0.89 & -0.62 & -0.9 & & -0.7 & -0.74 & -0.74 & -0.89 & -0.8 & & .68 & -0.76 & -0.5 & $x$ & $x$ & $x$ & $x$ & -0.79 & -0.77 & -0.69 & -0.75 & -0.58 & -0.74 & -0.77 \\
\hline
\end{tabular}

\section{REFERENCES}

1. Al-Bakri J.T., Suleiman A.S. 2004. NDVI response to rainfall in different ecological zones in Jordan. International Journal of Remote Sensing, 25(19), 3897-3912.

2. Barbosa H.A.T.V., Lakshmi K., Aydin E.G. 2009. Using the Satellite- Derived NDVI- OLR Feedbacks over West Sahel Africa to Assess Land- Atmosphere Responses to Environmental Change. In AIP Conference Proceedings. pp. 357-360.

3. Biniak-Pieróg M. 2008. Wpływ elementów agrometeorologicznych na zmienność zasobów wodnych gleby w półroczu zimowym. Współczesne Problemy Inżynierii Środowiska, VII.

4. Carlson T.C., Ripley D. a. 1997. On the relationship between NDVI, fractional vegetation cover, and leaf area index. Remote Sensing of Environment, 62, 241-252.

5. Chalfen M., Lyczko W., Plywaczyk L. 2014. The prognosis of influence of the Oder River waters dammed by Malczyce barrage on left bank areas. Journal of Water and Land Development, 21(1), 19-27.

6. Congedo L. 2016. Semi-Automatic Classification Plugin Documentation. Release 6.0.1.1.

7. Dąbrowska-Zielińska K., Ciołkosz A., Malińska A., Bartold M. 2011. Monitoring of agricultural drought in Poland using data derived from environmental satellite images. Geoinformation Issues, 3(1), 87-97.

8. Doroszewski A., Marcinkowska I. 1995. Llimatyczny bilans wodny sezonów wegetacyjnych 1921-1993 w Puławach. Środowisko Przyrodnicze Lubelszczyzny. Gleby i Klimat Lubelszczyzny, cz.
II - Klimat (J. Kołodziej, R. Turski, red.). Materiały z Konferencji Naukowej Lublin, 25 kwietnia 1994, 193-197.

9. Drusch M., Del Bello U., Carlier S., Colin O., Fernandez V., Gascon F., Hoersch B., Isola C., Laberinti P., Martimort P., Meygret A., Spoto F., Sy O., Marchese F., Bargellini P. 2012. Sentinel-2: ESA's Optical High-Resolution Mission for GMES Operational Services. Remote Sensing of Environment, 120, 25-36.

10. Dubicki A. i in. 2002. Zasoby wodne w dorzeczu górnej i środkowej Odry w warunkach suszy. IMGW, Warszawa, s. Atlasy i monografie.

11. Dzieżyc J, Nowak L., Panek K. Średnie regionalne niedobory opadów i potrzeby deszczowania roślin uprawnych na glebach lekkich i średnich. Zesz. Probl. Post. Nauk Roln., 314, 1987b, s. 35-47.

12. Gao B.C. 1996. NDWI - A normalized difference water index for remote sensing of vegetation liquid water from space. Remote Sensing of Environment, 58(3), 257-266.

13. Głuchowska B., Pływaczyk L. 2008. Wody gruntowe w dolinie Odry poniżej stopnia wodnego w Brzegu Dolnym. Wspólczesne Problemy Inżynierii Środowiska. V.

14. Groeneveld D.P., Baugh W.M. 2007. Correcting satellite data to detect vegetation signal for eco-hydrologic analyses. Journal of Hydrology, 344(1-2), 135-145.

15. Grzywna H., Dąbek P.B., Olszewska B. 2018. Analysis of moisture conditions in the lowland areas using high resolution spectral data from the Sentinel-2 satellite and the GIS tools. In Proc. 10th Conference on Interdisciplinary Problems in Environmental Protection and Engineering EKO-DOK 2018. 
16. Hisdal H., Tallaksen L.. 2000. Technical Report No. 6 Drought Event Definition.

17. Huete A., Didan K., Miura H., Rodriguez E.P., Gao X., Ferreira L.F. 2002. Overview of the radiometric and biopyhsical performance of the MODIS vegetation indices. Remote Sensing of Environment, $83,195-213$.

18. Jackson T.J., Chen D., Cosh M., Li F., Anderson M., Walthall C., Doriaswamy P., Hunt E.R. 2004. Vegetation water content mapping using Landsat data derived normalized difference water index for corn and soybeans. Remote Sensing of Environment, 92(4), 475-482.

19. Jankowiak J., Bieńkowski J. 2011. Kształtowanie I Wykorzystanie Zasobów Wodnych W Rolnictwie. (5), 39-48.

20. Jarząbek A., Sarna S., Karpiarz M. 2013. Ochrona przed suszą w planowaniu gospodarowania wodami.

21. Kycko M., Zagajewski B. 2013. Wpływ geometrii źródło promieniowania-roślina-detektor na wartość teledetekcyjnych wskaźników roślinności Assessment of geometry of radiation source-plantdetector on value of the remote sensing indices. Teledetekcja Środowiska, 49, 15-26.

22. Łabędzki L., Bąk B. 2015.a. Assessment of Soil Moisture on Permanent Grassland in Upper Noteć Valley Based on Soil Moisture Index. Ecological Engineering, 43, 153-159.

23. Łabędzki L., Bąk B. 2015.b. Method of IndicatorBased Assessment and Classification of Soil Moisture on Permanent. Infrastructure and Ecology of Rural Areas, (III), 515-531.

24. Łabędzki L., Bąk B. 2013. Monitoring i prognozowanie przebiegu i skutków deficytu wody na obszarach wiejskich. Infrastruktura i ekologia terenów wiejskich, (2), 65-76.

25. Lauzon N., Anctil F., Petrinovic J. 2004. Characterization of soil moisture conditions at temporal scales from a few days to annual. Hydrological Processes, 18(17), 3235-3254.

26. Martínez-Fernández J., González-Zamora A., Sánchez N., Gumuzzio A., Herrero-Jiménez C.M. 2016. Satellite soil moisture for agricultural drought monitoring: Assessment of the SMOS derived Soil Water Deficit Index. Remote Sensing of Environment, 177, 277-286.

27. Martyniak L., Dabrowska-Zielinska K., Szymczyk R., Gruszczynska M. 2007. Validation of satellitederived soil-vegetation indices for prognosis of spring cereals yield reduction under drought conditions - Case study from central-western Poland. Advances in Space Research, 39(1), 67-72.

28. Mohd Asaari M.S., Mishra P., Mertens S., Dhondt S., Inzé D., Wuyts N., Scheunders P. 2018. Closerange hyperspectral image analysis for the early detection of stress responses in individual plants in a high-throughput phenotyping platform. ISPRS Journal of Photogrammetry and Remote Sensing, $138,121-138$.

29. Nichol J.E., Abbas S. 2015. Integration of remote sensing datasets for local scale assessment and prediction of drought. Science of the Total Environment, 505, 503-507.

30. Nicolai-Shaw N., Zscheischler J., Hirschi M., Gudmundsson L., Seneviratne S.I. 2017. A drought event composite analysis using satellite remotesensing based soil moisture. Remote Sensing of Environment, 203, 216-225.

31. Nyc K. 1994. Rola retencji gruntowej w bilansowaniu zasobów wodnych. Zeszyty Naukowe Akademii Rolniczej we Wrocławiu, nr 248, Konferencje V: 247-251.

32. Olszewska B., Pływaczyk L., Łyczko W. 2012. Oddziaływanie spiętrzenia Odry stopniem wodnym w Brzegu dolnym na przepływach w cieku Jeziorka w latach 1971-2020. Water-EnvironmentRural Areas, 12(3), 161-170.

33. Pettorelli N., Vik J.O., Mysterud A., Gaillard J.M., Tucker C.J., Stenseth N.C. 2005. Using the satellite-derived NDVI to assess ecological responses to environmental change. Trends in Ecology and Evolution, 20(9), 503-510.

34. Du Plessis W.P. 1999. Linear regression relationships between NDVI, vegetation and rainfall in Etosha National Park, Namibia. Journal of Arid Environments, 42(4), 235-260.

35. Pływaczyk L., Olszewska B. 2014. Changes in the moisture content of the middle fen soils in the Odra river valley in the region of Brzeg Dolny in the vegetation periods 2004-2009. Journal of Ecological Engineering, 15(4), 61-68.

36. Schmidt H., Gitelson A. 2000. Temporal and spatial vegetation cover changes in Israeli transition zone: AVHRR-based assessment of rainfall impact. International Journal of Remote Sensing, 21(5), 997-1010.

37. Torres G.M., Lollato R.P., Ochsner T.E. 2013. Comparison of drought probability assessments based on atmospheric water deficit and soil water deficit. Agronomy Journal, 105(2), 428-436.

38. Wang D., Morton D., Masek J., Wu A., Nagol J., Xiong X., Levy R., Vermote E., Wolfe R. 2012. Impact of sensor degradation on the MODIS NDVI time series. Remote Sensing of Environment, 119, 55-61.

39. Wang J., Rich P.M., Price K.P. 2003. Temporal responses of NDVI to precipitation and temperature in the central Great Plains, USA. International Journal of Remote Sensing, 24(11), 2345-2364.

40. Wójtowicz A., Wójtowicz M., Piekarczyk J. 2005. Zastosowanie teledetekcji do monitorowania i oceny produktywności plantacji rzepaku. Oilseed Crops, XXVI, 269-276. 